\title{
Introduction
}

In Russia, the post-soviet state policy in the sphere of culture is characterized by a complex of challenges:

1) between current demands of the Russian society for values and the bankruptcy of the present cultural policy's abilities to form them;

2) between the present cultural diversity and undeveloped image of the Russian cultural space;

3) between the requirement for innovative technologies implementation in social activities and absence of opportunities for their practice in existing cultural institutions;

4) between the comprehension that the culture is not only and even not so much an "entertainment", as the only social institution functioning so as to bring an educational impact on an individual; to build their harmonious development and assist to a positive socialization and national identity.

These and many other challenges are implicitly reflected in the modern Russian legislation regulating the state cultural policy. The linguistic analysis of basic regulatory instruments (i.e. federal and regional laws) will allow us to bring the light on the way how these challenges appear inside the legislation and predetermine the low quality of the law enforcement in real life. Perhaps, the results of this analysis will highlight semiotic structures that are to be significantly improved. With this work a number of conceptual constructions of written legislation can be specified and, hereafter, by means of the law-making activity we can essentially amend the text of laws to make them performing more effectively.

\section{Background Papers}

Among different methods of linguistic analysis the content-analysis is the most widely used one. Its practice has a long history, and a variety of quantitative and qualitative use of this method is described in the work by B. Berelson [1]; the review on procedures and terms concerning the qualitative content analysis is introduced by U.H. Graneheim and B. Lundman [2]; H.F. Hsieh and S.E. Shannon develop special aspects of different content-analysis methods and point out strengths and weaknesses of each of them [3]; a sharper focus is brought by K. Krippendorff [4] and R.P. Weber [5] on the variety of procedures of the content-analysis; modern ways of the content-analysis involving the appliance of the software and its features were revealed for the first time ever in 1966 by R.J. Stone, D.C. Dunphy, \& M.S. Smith [6] and since that time they have become more complete with new studies [7;8]. Thus, in the present time the content-analysis is applied for specific researches in such facets as the health care [9], consumer behaviour [10], media analysis [11; 12; 13], nutritional researches [14], educational methods [15], advertisement [16], regional economy [17] and also for reasoning about the correctness in translation [18].

The variety of spheres where the content-analysis can serve is explained by its particular usefulness and ability to consider large data bases. With the means of the content-analysis these bases are transformed into concentrated arguments derived by clear processes of encoding and decoding. S. Stemler sheds the light on the main characteristics of these procedures and demonstrates how to avoid some mistakes within the content-analysis practice [19]. W. A. Scott in his work speaks in defence of the strictness of content-analysis as a scientific method as well as a sum of scientific procedures [20].

Such a wide practice of the content-analysis for qualitative and quantitative treatment of representational texts has resulted in the fact that legal texts, that include regulatory and legal acts, laws, writs and etc., can also be considered with the aid of the content-analysis. The possibility of linguistic and other semiotic approaches towards the analysis of legal documents was found in 1957 in the article by A. R. Anderson and O.K. Moore [21]. Today, S. Deakin overviews the whole long way that has been passed by legal ontological forms [22]. A. Vrij underlines the fact that is of the last importance for the current critical analysis: methods of analysis used for legal documents are able to evoke cognitive processes in terms of which these texts have been made up [23]. It has become possible to discover exactly what kinds of ideologemes are hidden beyond a formally impersonal legal text material and which ideological principles are included in a regulatory act, laying claim to establish the justice [24]. A detailed analysis of this problem is contained in the article by A.Hunt [25] as well as in the book by P. Goodrich [26].

Some researchers claim, that particular methods provide us with an opportunity to educe and assess psychological motives and intentions of a law-maker. Almost all the laws need a constant content-analysis in order to make the content of the texts independent from psychological sets of its author. The particular ground for the necessity of the content-analysis use in laws can be found in the work by B.G. Amado, R. Arce and F. Fariña [27]. Today, the content-analysis of legal documents is held in the context of feminism [28] and religious studies [29].

There also is a full-scale study by R.A. Falk concerning the differences in the status of a law in the whole diversity of societies and cultures [30]. By supporting of the main ideas, put forth by the scientist, we would like to use the contentanalysis within the studying of the subject of laws being currently in the force in Russia. We assume that this research will give an option to analyze critically the legal text and identify its weaknesses. On the basis of this critical analysis we further can give recommendations on changing regional laws, so as they are to increase their regulatory role and bring about the justice and supremacy of the law in uneasy social relationships in Russia.

\section{Data and Methods}

Within the contemporary humanities a content analysis is understood as the most rigorous scientific method in working with information. A necessary requirement for this analysis procedure is a physical information carrier. Thus, to carry out the content analysis in the context of the conceptual cultural research it is necessary to find such a text or a corpus of texts in which a word (i.e. names of concepts) performs as a key element (the analysis of quantity) and to analyse particular features of this concept understanding in a particular text. 
The choice of regulatory documents of the Siberian Federal District as an object for the content analysis is reasoned by its strategic importance within the whole country: the region is geographically located in the very middle of Russia, so as its position provides economical, transport and socio-cultural unity of the whole territory. This means that the population living in the Siberian Federal District performs a crucial geopolitical function, as by the fact of their presence in this area they keep the integrity of Russia.

To create more complete idea of cultural processes taking place in the Russian Federation, apart regional laws the Federal Law - the Principles of the Legislation of the Russian Federation on Culture - has also been considered.

The law performs as a meaningful text that determines the state policy and the social legitimacy in particular facets of social and economical relations. Besides, the law has a number of special features that are important for the content analysis procedure.

Firstly, it is the data considered from all the points of view, made up by dozens of experts at different spheres and not once but many times tested and read. Therefore, it can be assumed that there are no spontaneous words or meanings that do not reflect common situations or content.

Secondly, the text of laws is a thoroughly adjusted meaning complex where each of the elements has a contentrelated and logical grounds. At the same time, the law covers a large semantic field, subjected to some dominant ideas (targets), i.e. what is called as the basic content: it can be caught by a naked eye and primarily went through the intuitive analysis. Still, there also is a secondary and tertiary semantic sets that can be indicated with specific methods and with the help of the content analysis in particular.

In this article the method of content-analysis has been used for the regional laws concerning the culture peculiar to the present Russian Federation. Through these laws the state cultural policy is made and implemented. The Russian Federation is an enormous country where the united state system regulates a number of regions, often essentially different from each other in terms of climate, landmark, ethnic, gender, economic and demographic characteristics. At the Federal level the state cultural policy is formed in two directions: to create and strengthen the national cultural space; 2) to support specific regional cultural projects reflecting the uniqueness of the social and cultural space of these regions. In this way, the first step is dedicated to the making of the Federal Law on Culture which performs a basis for the Russian legislation in the sphere of culture. On the ground of this Federal Law, all the federal subjects develop their own laws concerning the culture. In this analysis such laws, operating in subjects of the Siberian Federal District, are concerned.

The choice of this administrative-territorial unit of the Russian Federation is determined by its strategic meaning for the country: the region is geographically located in the very middle of Russia, so as its position provides economical, transport and socio-cultural unity of the whole territory. This means that the population living in the Siberian Federal District performs a crucial geopolitical function, since by the fact of their presence in this area they keep the integrity of Russia.

The district was founded in the $13^{\text {th }}$ May, 2000. The Siberian Federal District (here and after - SFD) consists of 12 subjects of the Russian Federation (here and after - Russia). The territory of SFD makes $30 \%$ of the whole territory of this country; its population accounts for $20.06 \mathrm{~m}$ of people (here and after - population census data of 2010). The Siberian territory contains main reserves of natural resources. The gross regional product comes for 11, 4\% of the national GDP. In 2001 the whole share in industrial contribution to the Russian Federation corresponded to 12, 4\%.

The Siberian Federal District is a home for the population of 70 thousands of people, 18 nationalities and indigenous peoples of the North and Siberia (more than a one third of 45 indigenous peoples of the North and Siberia living in the Russia Federation).

There also is the Russian Academy of Sciences (Siberian Branch) that includes more than 100 research and development organizations and Siberian Federal University as one of the leading university in Siberia and Far East.

The Siberian Federal District plays a special role in building All-Russian cultural processes. It takes high positions upon major ratings, namely in: the number of theatre-goers for 1000 people -205 ( $3^{\text {rd }}$ place in Russia); the number of museum visits for 1000 people -342 ( $3^{\text {rd }}$ place in Russia); the library holdings of public libraries for 1000 people (examples) -6465 ( $5^{\text {th }}$ place in Russia); newspaper issues for 1000 people (one-time edition, examples) $-283\left(7^{\text {th }}\right.$ place in Russia). The Interregional Association "Siberian Accord", which includes subjects of the SFD, has the coordination board on the culture aimed at carrying out general approaches and methods of the state cultural policy building within the region.

Thirdly, the text of law reflects the main idea and content of what the government wants to deliver to the residents. This is not only about a narrow circle of the ruling elite, but also about the general public. The law is an intellectual material that is considered to be its primary virtue. The text of laws is clear to an educated man and especially to intellectuals. The last mentioned fact determines the other advantage, i.e. the ability to express the main ideas in the simpliest but laconic way.

In that manner, the laws selected for the content analysis reflect the modern Russian state ideology and policy in the sphere of culture in a sufficiently complete manner.

To understand conceptual aspects of the state cultural policy the following regulatory instruments were concerned under the content analysis:

-the Law of the Russian Federation № 3612-1 "Bases of the Legislation of the Russian Federation on Culture" dated 09.10.1992 (read with the Federal Laws of the Russian Federation №115-Ф3 dated on 23.06.1999, №122-Ф3 dated on 22.08.2004, №199-Ф3 dated on 31.12.2005, №175-Ф3 dated on 03.11.2006, №258-Ф3 dated on 29.12.2006, №160-Ф3 dated on 23.07.2008, № 335-Ф3 dated on 21.12.2009, amended by Federal Laws № 150-Ф3 dated on 27.12.2000, № 194Ф3 dated on 30.12.2001, № 176-Ф3 dated on 24.12.2002, № 186-Ф3 dated on 23.12.2003); 
- the Law of the Republic of Altai № 20-55 “On Culture” dated on 15.02.2001 (read with the Laws of the Republic of Altai № 24-63 dated on 12.09.2001, № 17-14 dated on 11.12.2003, № 84-P3 dated on 17.11.2006, № 26-P3 dated on 14.05.2007);

- the Law of the Republic of Buryatiya № 246-I "On Culture" dated on 01.02.1996 (read with the Laws of the Republic of Buryatiya № 622-III dated on 29.12.2003, № 994-III dated on 27.12.2004, № 1521-III dated on 07.03.2006, № 1619-III dated on 04.05.2006, № 2519-III dated on 08.10.2007, № 1045-IV dated on 07.10.2009 amended by the Laws of the Republic of Buryatiya № 897-II dated on 27.12.2001, № 184-III dated on 09.01.2003, № 592-III dated on 08.01.2004, № 2057-III dated on 28.12.2006, № 2625-III dated on 09.11.2007, № 624-IV dated on 22.11.2008, № 738-IV dated on 16.03.2009, by the Resolution of the Supreme Court of the Republic of Buryatiya.

- the Law of the Republic of Tuva № 261 "On Culture” dated on 03.04.1995 (read with the Laws of the Republic of Tuva № 879 dated on 12.02.2001, № 272 BX-1 dated on 10.07.2003, № 725 BX-1 dated on 12.05.2004, № 946 BX-1 dated on 17.12.2004, № 1897 BX-1 dated on 13.07.2006, № 193 BX-2 dated on 18.06.2007 amended by the Law of the Republic of Tuva № 604 BX-1 dated on 15.02.2010);

- the Law of the Republic of Khakassia № 30-3PX "On Culture” dated on 28.06.2006 (read with the Laws of the Republic of Khakasia № 66-3PX dated on 01.11.2007, № 49-3PX dated on 09.06.2009, № 2-3PX dated on 15.02.2010);

- the Law of the Zabaikalye Territory № 154-33K "On Culture” dated on 01.04.2009 (read with the Law of the Zabaikalye Territory № 347-33K dated on 29.03.2010);

- the Law of the Krasnoyarsk Region № 2-190 "On Culture" dated on 28.06.2007 (read with the Laws of the Krasnoyarsk Region № 6-1867 dated on 26.06.2008, № 7-2430 dated on 18.11.2008, № 8-3612 dated on 07.07.2009, № 94243 dated on 24.12.2009);

- the Law of the Irkutsk Region № 154-03 “On the State Support of Culture in the Irkutsk Region" dated on 29.12.2007 (read with the Law of the Irkutsk Region № 9-03 dated on 05.03.2010);

- the Law of the Kemerovo Region № 26-O3 "On Culture" dated on 14.02.2005 (read with the Laws of the Kemerovo Region № 62-O3 dated on 04.06.2007, № 200-O3 dated on 27.12.2007, № 135-O3 dated on 29.12.2008);

- the Law of the Novosibirsk Region № 124-O3 “On Culture in the Novosibirsk Region” dated on 07.07.2007 (read with the Laws of the Novosibirsk Region № 250-O3 dated on 02.07.2008, № 286-O3 dated on 04.12.2008);

- the Law of the Tomsk Region № 112-O3 “On Realization of the State Policy in the Sphere of Culture and Arts in the Tomsk Region” dated on 13.06.2007 (read with the Laws of the Tomsk Region № 267-O3 dated on 17.12.2007, № 253-O3 dated on 24.11.2009, № 254-O3 dated on 24.11.2009).

It is important to note that two regions of the Siberian Federal District (the Altai Region and Omsk Region) still do not have laws that regulate the development of the state cultural policy despite the existence of laws on separate spheres of cultural and leisure activity, concerning in particular library and museum services. Consequently, the content analysis has been done for 10 regional and 1 federal law on culture in their latest version.

\section{Results}

To reveal conceptual aspects of the state cultural policy we further shall introduce a fundamental idea on the basis of which the content analysis is built. We hold an opinion that such an idea is the concept "culture" taken with all its derivatives (i.e. cultures, by the culture, for the culture, etc) together with all the semantic expressions which surround them.

In the modern Russian language the word "culture" has a great number of meanings, which can roughly be divided into the following groups: 1) meanings related to academic studies of the culture; 2) meanings related to the state policy of the Russian Federation; 3) meanings gained from the every-day speech; 4) meaning related to the field of agriculture.

At this time, in the Russian science the unit "culture" is defined as: 1) a system of values; 2) a system of signs; 3) all kinds of human activities; 4) formation of ideals, creation of models and examples.

In the context of the current scientific discourse, there is a critical discussion about each of these meanings. Thus, "culture" is set in opposition to "nature" or "natura". In academic researches "culture" is quite frequently identified with "enlightenment". For example, Nikolai Roerikh suggested "culture" being understood as "a cult of Ura", where "Ur" is an Old Russian name for the "light". In this respect "culture" obtains the meaning of "a cult of Light", "enlightenment" and "education". The Russian academic tradition in cultural studies is based on two main lines: 1) as the German classic tradition rested upon G. Hegel's philosophy, wherein the culture is seen as creation, possession and transfer of ideals; 2) British, Italian, French and neo-Marxian tradition where cultural studies are related to the critics on cultural hegemony of one economy class over others. The Russian study of the culture includes both of these traditions. The first one is being developed under the title "culturology", while the other one has the name "study of culture", "cultural studies" or "cultural sociology".

During the Soviet and post-Soviet eras of the Russian history there are executive authorities, which accomplish a function of "state cultural management". Both at the Federal and sub-Federal levels there are Ministries of Cultural Affairs, a lot of cultural offices and departments perform in different municipalities. In this very sense, "culture" is an economic "sector" which comprises the activity performed by public agencies and "cultural" organizations, i.e. museums, clubs, theatres, philharmonic halls, libraries, zoos, ethnic culture centers, artistic ensembles and unions. These organizations receive grants from the state budget: the union of composers, union of artists, writers, as well as publishing houses, institutions for extended artistic education, higher education institutions (universities of culture, institutes of arts, 
conservatories, choreographic schools, acting schools academies of music, etc.). A lot of people take part in the economy of culture; it has a developed bureaucratic system with a great number of governmental and municipal servants.

In the everyday language the word "culture" involves "etiquette", "politesse" or "getting a specific level of education". A "man of culture" is a person who masters the rules of etiquette, has an appearance reflecting their high social status, has a higher education, and who is characterized by kindness in any actual communication.

In the agricultural sphere the word "culture" differentiates plant varieties "artificially" bred by a man from wildings. Such cultures include crops (wheat, rye, barley, buckwheat and etc.), vegetables (beet, carrot, cucumber, tomatoes), fruit trees (apple-tree, pear-tree, plum tree), berries (strawberry, raspberry), industrial plants (cotton, linen). These plants have "wild" forms, uncultivated forms, so as they live in the nature "without human influence", together with sorts fancied by men. Such selection varieties are called "cultures" or "cultivated".

In the Federal and regional laws concerning culture the element "culture" is understood not within its academic meaning, but in the context of economy of culture regulated by the Russian state, i.e. within the meaning of a special field of the post-Soviet economy.

Still, the meaning of the word "culture" within the state policy is connected not with the whole sphere of this economy, but with the practice of a specifically educational (artistic and popular or artistic and educational in particular) activity as well as with "collecting", "cumulating" and with studying of historical and cultural materials with folk and ethno features.

One can note a certain contradiction between academic researchers in the field of culture and perception of the culture in the context of the state policy of the Russian Federation. Sometimes the residents expect that the culture as a system of values, signs, types of activity, ideals, patterns and models, would go through the creation of regulatory acts at the Federal and regional levels, while officials and municipal servants understand this subject as a sector of economy. The present "Constitution of the Russian Federation" contains the prohibition on the state ideology building. If in the Federal and regional laws concerning culture the component "culture" is interpreted as the system of values or ideals, then this will implies the return of the state ideology - the thing which contravenes the "Constitution of the Russian Federation".

There also can be a certain gap between understanding the culture within the economy of culture (as the state policy item) and the academic perception of the culture as the most important sphere of the human activity on creation, transfer and preservation of ideals, samples and models (both in economic and spirit spheres). This gap within different understandings appears at the level of the actual state cultural policy, when state conceptions, strategies, special-purpose programs and project involve only the content related to artistic amateur performances, folk and ethnic movements, historical and cultural memorials, artistic and educating activities and etc.

It is worth noting, that there are several meanings of the culture even within the narrow context of its "field" perception. There are so called "cultural institutions" which are traditional for the Soviet and post-Soviet Russia and which are related to such field approach to the culture - museums, theatres, libraries, cultural and leisure centers, concert halls, heritage samples, which are realized as the "culture" in the mind of many people and public and municipal servants. However, today this sphere seems to be impossible without publishing, cinema, sound records, computer games, design, architecture, fashion, radio and television. Such notions as "cultural environment", "cultural space", "culture of life necessities" are making their appearance now, yet as many other terms defining a number of specific (cultural) conditions of existence, formation and activity of physically-challenged people and social groups. In addition, it is also pointed out that the cultural environment is increasingly being improved by such institutions as night clubs, book stores, festivals or modern information technologies such as the Internet.

Thus, in the modern Russian society, the word "culture" has a wide range of meanings. There is a lively discussion about the culture as a philosophical notion. At the same time, the culture is involved in the state legal documents as an object of the state policy. Alternatively, the word "culture" has a widespread appreciation in the everyday communication in the context of a positive evaluation of social features of people, wherein the qualification as a "cultured man" implies a compliment or recognition.

Initially, only 1 document out of 11 contained in its title the understanding of culture as one of the types of the state policy (the law "Concerning Realization of the State Policy in the Sphere of Culture and Arts in the Tomsk Region"). In other cases titles of the laws including the federal one failed to imply not only the state cultural policy but also explicitation relating to the conceptual vision of what the culture is: the ideal building part of the human life and activity, branch, sphere, etc. In this sense $91 \%$ of all the selected data has the general title "Concerning Culture" that little reflects understanding of culture as one of the main types of the state policy.

Today, the basic document that determines the development of the state cultural policy is Law of the Russian Federation № 3612-1 “Bases of the Legislation of the Russian Federation on Culture” enforced on October 9, in 1992, i.e. almost two decades ago. That brings us to say about the fact that despite a set of amendments (the latest one is dated on 2009), this law has already been obsolescent and, thus, demands upgrading.

Further we need to indicate the concepts defined by the authors of this Law as the basic ones and the meaning of which has been revealed in the text: cultural activity; cultural values; cultural goods; creative activity; creative specialist; cultural dignity of peoples and national groups; cultural heritage of people of the Russian Federation; cultural aspects of the programmes of development; cultural state policy (the state policy in the sphere of culture). All in all there are 10 notions.

The static analysis of the Law text indicates the following results:

- the number of words in the document is 5595; 
- the number of words "kultura" ("culture") and its derivatives in different cases is 146, i.e. $2.6 \%$ from the total amount of words within the text.

\section{Table 1}

The most frequent word combinations that include the adjectives with the stem "kultur" ("cultur") are: kulturnaya deyatelnost' - 29 (cultural activity), kulturniye tsennosti - 24 (cultural values), kulturnoye naslediye - 20 (cultural heritage), kulturnoye dostoyaniye - 8 (cultural assets), kulturnaya politika - 4 (cultural policy), kulturnoye razvitiye - 3 (cultural development), kulturnoye sotrudnichestvo - 2 (cultural cooperation).

Finally, under the comparison of basic concepts marked in the Law and the most commonly encountered word combinations we conclude that the idea "cultural policy" occurs only 4 times in the text, that makes only $3 \%$ from the all word combinations containing the abovementioned adjective. Thus, it can be argued that a legislator understands the culture not as a type of the state policy, but as a certain sphere, thus, narrowing the state approach down to a sectoral one. This can also be supported by the fact that the second place in the frequency of use is taken by the expression "kulturniye organizatsii" ("cultural organizations"). Consequently, it is convincible that the main tools that make "culture" operating are certain organizations both governmental and non-governmental ones, that cannot be said about cultural specialists since this word combination occurs only two times (refer to Table 1).

The basic document which determines the development of the state cultural policy in the Republic of Altai is the Law of the Republic of Altai № 20-55 “On Culture” dated on 15.02.2001.

Here we also should mark the concepts defined by the law-makers as the essential ones: cultural activity; cultural value; cultural goods; cultural arrangement, or in sum, there are 4 items.

The static analysis of the Law text indicates the following results:

- the number of words in the document is 2695 ;

- the number of words "kultura" ("culture") and its derivatives in different cases is 92 , i.e. $3.4 \%$ from the total amount of words within the text.

Table 2.

The number of adjectives that include the stem "kultur" ("cultur") is 37 , i.e. $1.3 \%$ from the total number of words used in the text. Among them the most common ones are: kulturnaya deyatelnost' - 12 (cultural activity), kulturniye tsennosti - 5 (cultural values), kulturnaya politika - 4 (cultural policy), kulturnoye naslediye - 4 (cultural heritage), kulturnoye prostranstvo - 2 (cultural space).

Having concerned the most common word combinations, we can conclude that "cultural policy" is on the third place in the frequency of usage. However the Law does not contain the definition that provides an opportunity to assume the authors using this expressions as a synonym to the word combination "the policy in the sphere of culture" (refer to Table 2), that disagrees with its original meaning.

Going further and speaking about the basic document regulating the state cultural policy in the Republic of Buryatiya (i.e. Law of the Republic of Buryatiya № 246-I “On Culture” dated on 01.02.1996 ), we also mark the following concepts: cultural activity; cultural value; cultural goods; creative activity; creative specialist; cultural dignity of peoples and national groups; cultural heritage of people of the Republic of Buryatiya; state support for culture; national (ethnic) culture; state cultural policy (state policy in the sphere of cultural development), culture and arts organizations. In total, we have found 12 concepts.

The static analysis of the Law text indicates the following results:

- the number of words in the document is 4480;

- the number of words "kultura" ("culture") and its derivatives in different cases is 114, i.e. $2.5 \%$ from the total amount of words within the text.

\section{Table 3}

The number of adjectives that include the stem "kultur" ("cultur") is 77 , i.e. $1.7 \%$ from the total amount of words used in the text; the most common adjectives are: kulturnaya deyatelnost' - 18 (cultural activity), kulturniye tsennosti - 17 (cultural values), kulturnoye naslediye - 13 (cultural heritage), kulturnoye dostoyaniye - 8 (cultural assets), kulturniy obmen - 6 (cultural exchange), kulturnaya politika - 2 (cultural policy).

Similar to the case of the Federal Law, the notion of culture can be found only twice in the text, representing only $2.5 \%$ from all the word combinations containing the stem marked above (refer to Table 3 ).

The basic document which determines the development of the state cultural policy in the Republic of Altai is the Law of the Republic of Tuva № 261 “On Culture” dated on 03.04.1995.

We are to mark the concepts defined by the law-makers as the basic ones: cultural activity; cultural value; cultural goods; creative activity; creative specialist; cultural dignity of peoples and national groups; historical and cultural heritage; cultural assets of people of the Republic of Tuva; cultural aspects of development programmes; the state cultural policy (the policy of the state in the sphere of culture). All in all, there are 10 concepts.

The static analysis of the Law text indicates the following results:

- the number of words in the document is 5009;

- the number of words "kultura" ("culture") and its derivatives in different cases 126, i.e. $2.5 \%$ from the total amount of words within the text. 
Table 4.

The number of adjectives that include the stem "kultur" ("cultur") is 93, i.e. $1.8 \%$ from the total amount of words used in the text.

The most common word combinations including the adjectives with the stem "cultur" are: kulturnaya deyatelnost' - 24 (cultural activity), kulturniye tsennosti - 21 (cultural values), kulturnoye naslediye - 11 (cultural heritage), kulturnoye dostoyaniye - 6 (cultural assets), kulturnaya politika - 4 (cultural policy), kulturnaya unikalnost' - 5 (cultural uniqueness), kulturniye fondi-3 (cultural foundations).

The basic document which determines the development of the state cultural policy in the Republic of Khakassia is the Law of the Republic of Khakassia № 30-3PX “On Culture” dated on 28.06.2006.

The static analysis of the Law text indicates the following results:

- the number of words in the document is 3345 ;

- the number of words "kultura" ("culture") and its derivatives in different cases is 113, i.e. $3.3 \%$ from the total amount of words within the text.

We are to mark the concepts defined by the law-makers as the basic ones: cultural organizations; protection and preservation of the cultural heritage objects of the regional significance; folk artistic craft; young specialist.

Table 5 .

The number of adjectives with the stem "kultur" is 52 , i.e. $1.5 \%$ from the total amount of words used in the text.

The most common word combinations including the adjectives with this stem are: kulturnaya deyatelnost' - 17 (cultural activity), kulturnoye naslediye - 10 (cultural heritage), kulturniye tsennosti - 9 (cultural values), kulturnaya politika - 2 (cultural policy), kulturnaoye sotrudnichestvo - 2 (cultural cooperation).

Similar to the case with the Law of the Republic of Altai, the analysis of the most common word combinations shows that "kulturnaya politika" ("cultural policy") takes the fourth place in the frequency of use. Still the Law does not include its definition, that brings us to say about the authors using this form as a synonym to "the policy in the sphere of culture", that does not coincide with its original meaning. Once again, that leads to the narrowly specific understanding of the culture proved by the fact that the word combination "organizatsii kulturi" (cultural organizations) has been ranked first.

The basic document which determines the development of the state cultural policy in the Zabaikalye Territory is the Law of the Zabaikalye Territory № 154-33K “On Culture” dated on 01.04.2009.

The static analysis of the Law text indicates the following results:

- the number of words in the document is 1354 ;

- the number of words "kultura" ("culture") and its derivatives in different cases is 41 , i.e. $3 \%$ from the total amount of words within the text.

Table 6

The number of adjectives with the stem "kultur" is 4, i.e. $0.02 \%$ from the total amount of words used in the text.

The most common word combinations including the adjectives with this stem are: kulturnoye naslediye - 3 (cultural heritage); kulturnoye dostoyaniye - 1 (cultural assets).

It should be noted that the authors of the Law do not define any basic terms. Thus, we assume that the text does not clarify the fact concerning the law-makers' understanding of the conceptual aspects of the state cultural policy. Presumably, it is connected with the evidence that the Zabaikalye Territory is a young federal region. In this sense, its regulative base is formed quite actively, and, thus, the law-maker can leave some basic ideas out of account. As for this part, it leads to an increase in the range of the Law interpretations, since it does not have definitions even for the most frequently used word combinations, such as "organizatsii kulturi" (cultural organizations). Moreover, the complication in identifying the conceptual aspects in the state cultural policy on this territory supports the absence of substantially all the specific Laws which are enforced in other federal members of the Siberian Federal District.

The basic document which determines the development of the state cultural policy on the Krasnoyarsk territory is the Law of the Krasnoyarsk Region № 2-190 “On Culture” dated on 28.06.2007.

Here we need to indicate the concepts defined by the authors of this Law as the basic ones and the meaning of which has been revealed in the text: cultural organizations; cultural assets of the region; national register of the most valuable cultural heritage sites of the Krasnoyarsk Region; creative specialist; folk artistic ensembles; folklore of the North indigenous minorities of the Krasnoyarsk Region; folklore holder; social and cultural project; creative heritage. All in all, there are 9 items.

The static analysis of the Law text indicates the following results:

- the number of words in the document is 4015;

- the number of words "kultura" ("culture") and its derivatives in different cases is 130, i.e. $3.2 \%$ from the total amount of words within the text.

Table 7.

The number of adjectives with the stem "kultur" is 50 , i.e. $1.2 \%$ from the total amount of words used in the text. 
The most common word combinations including the adjectives with this stem are: kulturnoye naslediye - 17 (cultural heritage); kulturniye tsennosti - 10 (cultural values), kulturnaya deyatelnost' - 5 (cultural activity), kulturnaya samobytnost' - 5 (cultural uniqueness), kulturnoye dostoyaniye - 3 (cultural assets), kulturniye obmeni - 4 (cultural exchanges).

The analysis of the basic ideas, defined by the law-makers; of the words, framing the concept "culture"; word combinations that include adjectives with the stem "kultur" has revealed the fact that the idea "cultural policy" is not used in the text at all. This comes into a certain conflict with the fact that there are Central directions on the strategy of the cultural policy for the period of 2009 - 2020 carried out and adopted by the Krasnoyarsk Region Government. Therefore, conceptual aspects of the state cultural policy, implied in the conceptual document, disagree with the current terminology and content of the main law.

The basic document which determines the development of the state cultural policy on the Irkutsk territory is the Law of the Irkutsk Region № 154-оз “On the State Support of Culture in the Irkutsk Region” dated on 29.12.2007.

The static analysis of the Law text indicates the following results:

- the number of words in the document is 1118 ;

- the number of words "kultura" ("culture") and its derivatives in different cases is 34 , i.e. $3 \%$ from the total amount of words within the text.

Table 8 .

The number of adjectives with the stem "kultur" is 1 , i.e. $0.0008 \%$ from the total amount of words used in the text. (cultural events).

It bears mentioning, that the authors of the Law have not defined its basic terms. Thus, as we can conclude, the text does not cast any light upon the understanding of the conceptual aspects of the state cultural policy: this is supported by the absence of that idea itself.

The basic document which determines the development of the state cultural policy on the Kemerovo territory is the Law of the Kemerovo Region № 26-O3 “On Culture” dated on 14.02.2005.

Once again, we need to indicate the concepts defined by the authors of this Law as the basic ones and the meaning of which has been revealed in the text: cultural activity, cultural organizations, artistic folk crafts.

The static analysis of the Law text indicates the following results:

- the number of words in the document is 1962 ;

- the number of words "kultura" ("culture") and its derivatives in different cases 61, i.e. $3.1 \%$ from the total amount of words within the text.

Table 9.

The number of adjectives with the stem "kultur" is 31 , i.e. $1.5 \%$ from the total amount of words used in the text.

The most common word combinations that contains the adjectives with this stem are kulturnoye dostoyaniye - 9 (cultural assets); kulturnaya deyatelnost' - 7 (cultural activity); kulturnoye naslediye - 7 (cultural heritage); kulturniye tsennosti - 5 (cultural values); kulturniye obyedineniya - 2 (cultural thrusts).

The analysis of the basic ideas, defined by the law-makers; of the words, framing the concept "culture"; word combinations that include adjectives with the stem "kultur" has revealed the fact that the idea "cultural policy" is not used in the text at all. That leads to the narrowly specific understanding of the culture proved by the fact that the word combination "organizatsii kulturi" (cultural organizations) has been ranked first.

The basic document which determines the development of the state cultural policy on the Novosibirsk Region is the Law of the Novosibirsk Region № 124-O3 “On Culture in the Novosibirsk Region” dated on 07.07.2007.

The concepts defined by the law-maker as basic ones are the following: cultural activity; cultural organization; cultural institution; folk artistic crafts; cultural specialist.

The static analysis of the Law text indicates the following results:

- the number of words in the document is 2963 ;

- the number of words "kultura" ("culture") and its derivatives is 106 , i.e. $3.5 \%$ from the total amount of words within the text.

Table 10.

The number of adjectives with the stem "kultur" is 24 , i.e. $0.8 \%$ from the total amount of words used in the text.

The most common word combinations that contain the adjectives with this stem are: kulturnaya deyatelnost' -8 (cultural activity); kulturniye tsennosti - 5 (cultural values), kulturnoye naslediye - 4 (cultural heritage).

Similar to the case of the Law of the Kemerovo Region "On Culture", the analysis of the basic ideas, defined by the law-makers; of the words, framing the concept "culture"; word combinations that include adjectives with the stem "kultur" has revealed the fact that the idea "cultural policy" is not used in the text at all. That leads to the narrowly specific understanding of the culture proved by the fact that the word combination "organizatsii kulturi" (cultural organizations) has been ranked second in the frequency of use (refer to Table 10). 
The basic document which determines the development of the state cultural policy in the Tomsk Region is the Law of the Tomsk Region № 112-O3 "On Realization of the State Policy in the Sphere of Culture and Arts in the Tomsk Region" dated on 13.06.2007.

The static analysis of the Law text indicates the following results:

- the number of words in the document is 2236 ;

the number of words "kultura" ("culture") and its derivatives in different cases 69, i.e. $3 \%$ from the total amount of words within the text.

\section{Table 11}

The number of adjectives with the stem "kultur" is 18 , i.e. $0.8 \%$ from the total amount of words used in the text.

The most common word combinations that contain the adjectives with this stem are: kulturnaya deyatelnost' -8 (cultural activity); kulturniye tsennosti - 3 (cultural values), kulturnoye naslediye - 2 (cultural heritage).

It is also should be mentioned that the authors of the Law have not defined its basic terms. Thus, the text does not clarify the understanding of the conceptual aspects of the state cultural policy as confirmed that the text of the Law has minimum word combinations which include the adjectives with the stem "kultur": there is only $0.8 \%$ from the total amount of the words. This is also can be characterized by the narrowly specific understanding of the culture proved by the fact that the word combination "uchrezjdeniya kulturi" (cultural institutions) has been ranked first (refer to Table 11).

\section{Table 12.}

As reflected by the table most of the words "kultura" and its derivatives can be found in the text of the Law of the Russian Federation № 3612-1 "Bases of the Legislation of the Russian Federation on Culture", that is quite reasonable since it is the basic law regulating the development of the cultural policy in the Russian Federation. In this way, this text contains the most part of the articles, and theoretically is to concern all the aspects related to the state cultural policy implementation. Moreover, on the ground of this Law special regulatory acts covering certain types of the social and cultural activity have been carried out.

According to the quantitative analysis of the words, it is fair to assume that the Laws on culture operating in four federal members (in the Zabaikalye Region, Irkutsk, Kemerovo and Tomsk Regions) least of all reflect the logic of the regional cultural policy development, since the number of the words in these Laws is more than twice as small as in the Federal Law.

The frequency rate for the words "kultura" (culture) and its derivatives in regulatory legal acts varies from $2.5 \%$ to $3.5 \%$ from the total number of the words used in the texts. Quite notably, the lowest index is showed in the Law of the Republic of Buryatiya № 246-I "On Culture” which has been ranked third in the total number of the words performed in the text.

\section{Table 13.}

According to the Table 13 the first place in the frequency of usage is taken by the word "organizatsii" (organizations) or "uchrezjdeniya" (institutions), which in this context are concerned as synonyms - framing the concept "culture' and its derivatives.

As we see it, the best definition for this word is given in the Law of the Novosibirsk Region № 124-O3 “On Culture in the Novosibirsk Region": "cultural organization is an organization that is founded with the intention of cultural activity performance (i.e. theatrical entertainment organizations, concert organizations, libraries, museums, exhibition halls and centres, planetariums, culture centres, clubs, folk art centres, recreation and entertainment parks, cinemas, video rental and film-viewer organizations; organizations acting in the sphere of preservation, usage, promotion and state protection of cultural heritage sites; other organizations that serve in the sphere of culture) as well as educational institutions in the sphere of culture and art".

Thus, as it can be stated further, that the main instrument of the cultural policy implementation is presented by certain organizations both governmental and non-governmental ones. At the same time, the law-makers have not mentioned cultural specialists since this word combination has been excluded from the list of the most common words.

Besides, almost in all the cases legislators precept the culture not as a separate type of the state policy, but as a certain area or sphere leading the state approach down to the narrowly specific one (refer to Table 13).

\section{Table 14}

As it follows from the comparative analysis of the basic terms defined by the authors and word combinations (referred to Table 14) the most frequently used terms are "kulturnaya deyatelnost", (cultural activity) and "kulturniye tsennosti" (cultural values). Full definitions of these concepts are included in the Law of the Russian Federation № 3612-1 "Bases of the Legislation of the Russian Federation on Culture": "cultural activity is a type of activity aimed at preservation, creation, promotion and acquisition of cultural values"; "cultural values are concerned as moral and ethical ideals, models and standards of behaviour, languages, dialects and subdialects, national traditions and customs, historical toponyms, folklore, artistic crafts, works of art and culture, results and methods of scientific researches on cultural activity, buildings that have cultural and historical value, installations, objects and technologies that are unique within the history and culture". 
Therefore, the law-maker indirectly considers the culture to be an ideal forming side of the human life, though ideal forming activity is assigned to cultural organizations and institutions, that contradicts their basic function including cultural services delivery to people.

Thus, the variety of meanings for the word "culture" within its today's usage in the Russian language is not reflected in the Law of the Russian Federation "Fundamentals of Legislation of the Russian Federation on Culture". The academic representation of the culture as a system of values, signs, types of activity, ideals, patterns, norms and models is absent in such a basic legal text. Still, it mainly reveals the meaning of this word as an economy sector, the state management of which has been "passed down" from the Soviet period within the history. This fact is proved by different word combinations used in the very text of the Law: organizatsii kulturi ("cultural organizations"), uchrezhdeniya kulturi ("cultural institutions"), prednpriiatiia kulturi ("cultural companies"), including libraries, museums, exhibition and concert halls, artistic schools for children, conservatories, higher schools of paintings, choreography and theatre.

The idea that in the Federal Law the word "culture" means "an economic sector controlled by the state" is also expressed by quite a frequent usage of the word combination rabotniki kulturi ("cultural specialists") that implies the idea of people who serve in organizations and institutions which are $100 \%$ originated by the state or municipal budget.

Another two term combinations based on the word "culture" also make themselves conspicuous: narodnaia kultura ("folk culture") and natsionalnaia kultura ("national culture"). It makes clear in the text of the Law that it is referred to so called "formal folklore", i.e. to works of musical, artistic, literature and performing arts, which have the state status as being "created by the nation", while in the real life, they are written or created by certain people -men of literature, artists, composers, playwrights, stage or film directors - all those who have a professional education.

Local law-makers are given some freedom in law-text creation. Has the meaning of the word "culture" expressed in these laws changed, or does its original acceptation formed by the Federal Law stay the same?

The Law of the Republic Altai "Concerning Culture" is characterized by not an addition, but narrowing in the set of meanings of the word "culture". Thus, linguistically, the Law does not contain the notion narodnaia kultura ("folk culture") and has only natsionalnaia kultura ("national culture"). That probably is connected with the fact that the first notion points at the Russian folklore, while the term "national culture" is assigned with the meaning "non-Russian folklore". Actually, the biggest part of fictional works, creation and representation of which relates to "folklore" of Altai's people, Yakut folklore, Buryat folklore and etc., is, as a matter of fact, composed by masters. In the context of the state cultural policy supporting an authorless folklore, it is easier for the participants of the cultural process to give the authorities anonymous works characterized by ethnic aspects, than to receive any support for the authors fictional works.

In the text of the Law of the Buryat Republic "Concerning Culture" a new meaning of the word "culture" appears. This meaning is expressed in the utterance kultura narodov respubliki Buryatiya ("the culture of Buryat peoples"), where the word narodi (peoples) is given in the plural. Such change in the meaning of the word "culture" is reasoned by the fact that authors of this Law understand the Republic as a living space not for one community with its own unique culture, but at least for two peoples, i.e. Russains and Buryat people. Apart from these two ethnic groups, the concerned word combination implicitly means the third type of peoples, i.e. indigenous peoples of Siberia, including the Soyots, amount to 50000 of people. Such existence of unique cultures in the Russian, Buryat and Soyot ethnos is implied in the text of the Law, or, in particular, within the expression kultura narodov respubliki Buryatiya ("the culture of Buryat peoples"). This very meaning is absent in the text of the Federal Law or in the Law of the Republic Altai.

Quite interesting extension (broadening) of the meaning can be found out in the Law of the Republic of Tuva "Concerning Culture". In comparison with the other Laws, it has a brand-new combination - mirovaia kultura ("world culture"). At the same time, this legal text has the meaning kultura narodov respubliki Tuva ("the culture of Tuvinian peoples"), which in this sense is understood as the difference between the Russian and Tuvinian ethnic cultures. The combination "world culture" widens the meaning of the word "culture" by including masterpieces and other works belonging to the world artistic culture. This set expression - world culture - is traditionally referred only to the sphere of art and religion, leaving out economy and politics. The appearance of this meaning in the Law can be explained in different ways. Perhaps, it is caused by the fact that the cultural elite in the Republic is focused not only on the Russian ethnic culture, taking it as an ideal example, but at the same time and at the same degree, on global cultural processes. Nevertheless, such a unique accession of the essence knows no equals either in the Federal Law, or in other regional legal text within the Siberian Federal District.

Narrowing in the set of meanings is found in the regional Law of the Republic of Khakassia "Concerning Culture". The text lacks the expression "world culture", "the culture of Khakassian peoples" or "folk culture". There only is a specific group of meanings related to the economy of culture: rabotniki kultury ("cultural specialists"), organizatsii kultury ("cultural organizations"), uchrezhdeniia kultury ("cultural organizations"). The only meaning of the culture in the context of "national culture" is left, and thus, within the legal text it reflects "the culture of Khakassian peoples". Despite of the fact, that this territory is occupied by the residents belonging to the unique ethnic group of Siberian aborigines, called Shors, the text does not possess any specific reference to the special state support for that type of ethnic group.

Even more considerable content narrowing of the word "culture" occurs in regional Laws of the Zabaikalye Territory, Irkutsk Region, Kemerovo Region and Tomsk Region. All the meanings of this word relate only to organizations and institutions, financially supported by the means of the state and municipal budgets. Phrases and, consequently, notions "national culture", "culture of peoples", "world culture" are not used in their texts. Obviously, these regional laws are purely aimed at regulating the budget process, and are not tied with any sort of unique ethnic cultures or world art processes. Although these regions are in the same way inhabited with Siberian aborigines, i.e. Hamnigans, Tofalars, 
Kumandins and Evenks, the Laws do not contain the word combination "culture of peoples in ... Region", as it is has been demonstrated in the Law of the Republic of Tuva and Buryatiya.

The word "culture" has the similar meaning in regional Laws of the Krasnoyarsk Territory and Novosibirsk Region. As against the other regional laws (i.e. in the Republic of Tuva and Buryatiya) they do not also imply any meanings related to the world culture or to cultures of people living within these territories. Linguistic contexts involve only the utterance "national culture". Taking into consideration the fact that the Krasnoyarsk Territory and Novosibirsk Region do not contain ethnonyms in titles, one may suppose that the meaning of this phrase is somewhat different as in the legal text of the Law of the Republic of Khakassia "Concerning Culture". While the last document refers to the case of Khakassian ethnic culture, then within the Krasnoyarsk Territory and Novosibirsk Region we speak about the Russian allnational culture, which is to various extent peculiar to all the regions of the Russian Federation.

Academic discussions around the philosophical meaning of the word "culture" have no impact on legal texts of Laws "Concerning Culture" at both the Federal and regional levels (i.e. within the Siberian Federal District). Up to some degree these texts include meanings of the word "culture" typical for everyday communication, since a declared target of these Laws is the creation of "a man of culture", i.e. people who follow the etiquette, know about artistic works of folklore, about museum and book collections, being held in different organizations which are supported by the state and municipal budgets. Thus, it is possible to state that lawmakers, working in the sphere of culture, have created and still do maintain the system of the meanings for the word "culture" in the context of a particular process, which is attributed not so much to a direct artistic creation or comfort of the urban space, not to values or ideals, but to financing of certain cultural practices and institutions from the state or municipal budget. A significant number of modern cultural practices find themselves outside the focus of the state cultural policy and consequently, they are being developed through a private initiative or by the means of modernizing procedures inside the state cultural policy.

\section{Conclusion}

On the ground of the content-analysis of the regulatory legal acts which provide implementation of the state cultural policy in the regions of the Siberian Federal District and on the basis of the Law of the Russian Federation № 3612-1 "Bases of the Legislation of the Russian Federation on Culture" we conclude the following:

- only 1 out of 11 concerned documents contains in its title the understanding of the culture as a type of the state policy. In other cases the Laws together with the Federal one fail to imply not only the state cultural policy, but even explicitation concerning the conceptual view of the state on the culture. In this regard, $91 \%$ of the analysed documents has a general title "On Culture", which does not at all reveal interpretation of the culture as one of the main types of the state policy;

- the Laws contain many inappropriate synonyms to such concept as "cultural policy" (i.e. the sector "culture", policy in the sphere of culture, the sphere of culture), which significantly misrepresent the role of the state;

- by introducing these synonyms the law-maker leads the state approach to the cultural policy implementation down to the narrowly specific one.

- the main instrument of the "culture" operating is represented by particular organizations both governmental and non-governmental ones.

- texts of some Laws do not cast any light on the authors' understanding of the conceptual aspects of the state cultural policy, as they do not contain basic terms. That causes diffusion of the functions related to the state cultural policy implementation.

- conceptual aspects laid in the basic documents on the state cultural policy implementation disagree with the current terminology and content of the main legal acts.

- there is a need in a detailed revision of the all existing regulatory legal acts delivering the state cultural policy implementation towards building a universal terminology and vesting the functions on the cultural policy implementation in the government as opposed to the statement of the departmental specific approach to the culture.

\section{Summary}

The content-analysis of the Russian federal and regional basic legislation on the cultural policy has indicated a need in a deep revision of all existing regulatory legal acts, which support the state cultural policy implementation towards building a universal terminology and vesting the functions on the cultural policy implementation in the government as opposed to the statement of the departmental specific approach to the culture.

\section{References}

1. Berelson, Bernard. 1952. Content analysis in communication research. Glencoe, Illinois: The Free Press.

2. Graneheim, Ulla. H., and Berit Lundman. 2004. Qualitative content analysis in nursing research: concepts, procedures and measures to achieve trustworthiness. Nurse education today. doi: 10.1016/j.nedt.2003.10.001.

3. Hsieh, Hsiu-Fang, and Sarah E. Shannon. 2005. Three approaches to qualitative content analysis. Qualitative health research 15(9): 1277-1288.

4. Krippendorff, Klaus. 2012. Content Analysis, An Introduction to Its Methodology. 3rd Edition. Thousand Oaks, CA: Sage Publications. 
5. Weber, Robert P. 1990. Basic content analysis. 2nd Edition. Newbury Park, CA: Sage university paper series on quantitative applications in the social sciences.

6. Stone, Philip. J., Dexter C. Dunphy, and Marshall S. Smith. 1966. The General Inquirer: A Computer Approach to Content Analysis. Cambridge, Mass: MIT Press

7. Lucas, Cristopher, Richard A. Nielsen, Margaret E. Roberts, Brandon M. Stewart, Alex Storer, and Dustin Tingley 2015. Computer-Assisted Text Analysis for Comparative Politics. Political Analysis. doi:10.1093/pan/mpu019

8. Stubbs, Michael. 1996. Computer-assisted studies of language and culture. In Text and Corpus Analysis, 1-15. Oxford: Blackwell.

9. Downe-Wamboldt, Barbara. 1992. Content analysis: method, applications, and issues. Health care for women international 13(3): 313-321.

10. Kassarjian, Harold. H. 1977. Content analysis in consumer research. Journal of consumer research 4 (1): 8-18.

11. Semetko, Holli. A., and Patricia M. Valkenburg. 2000. Framing European politics: A content analysis of press and television news. Journal of communication 50(2): 93-109.

12. Stanig, Piero. 2015. Regulation of speech and media coverage of corruption: an empirical analysis of the Mexican press. American Journal of Political Science 59(1): 175-193.

13. Rozina, Irina N. 2012. Discussion Forum as the Central Element of the Online Seminar: Content-Analysis of Posts by German Students. Journal of Siberian Federal University. Humanities \& Social Sciences 12 (5): 1823-1833

14. Kondracki, Nancy. L., Nancy S. Wellman, and Daniel R. Amundson. 2002. Content analysis: review of methods and their applications in nutrition education. Journal of nutrition education and behavior 34(4): 224-230.

15. De Wever, Bram, Tammy Schellens, Martin Valcke, and Hilde Van Keer. 2006. Content analysis schemes to analyze transcripts of online asynchronous discussion groups: A review. Computers \& Education 46(1): 6-28.

16. Kawooya, Dick, Amber Veverka and Tomas Lipinski. 2015. The Copyright Librarian: A Study of Advertising Trends for the Period 2006-2013. The Journal of Academic Librarianship 41(3): 341-349.

17. Nemirovsky, Valentin G. 2013. Population of the Region about Barriers to Effective Modernization (on the Materials of Social Research in Krasnoyarsk Krai). Journal of Siberian Federal University. Humanities \& Social Sciences 8 (6): 1142-1154.

18. Brislin, Richard W. 1980. Translation and content analysis of oral and written material. In Handbook of crosscultural psychology, Vol. 2, 349-444. Allyn \& Bacon, Boston, MA

19. Stemler, Steve. 2001. An overview of content analysis. Practical assessment, research \& evaluation, 7(17): 137146.

20. Scott, William A. 1955. Reliability of content analysis: The case of nominal scale coding. Public Opinion Quarterly 19: 321-325

21. Anderson, Alan R., and Omar K. Moore. 1957. The formal analysis of normative concepts. American Sociological Review 22: 9-17.

22. Deakin, Simon. 2015. Juridical Ontology: The Evolution of Legal Form. Historical Social Research, 40(1):170184.

23. Vrij, Aldert. 2015. Verbal Lie Detection Tools: Statement Validity Analysis, Reality Monitoring and Scientific Content Analysis. Detecting Deception: Current Challenges and Cognitive Approaches. doi: 10.1002/9781118510001.ch1.

24. Semyonova, Alexandra A. 2011. The Concept "State" in Local Culture of Krasnoyarsk: the Results of an Associative Experiment Based on the Method "Series of Thematic Associations». Journal of Siberian Federal University. Humanities \& Social Sciences 11 (4): 1526-1542

25. Goodrich, Peter. 1987. Legal discourse: Studies in linguistics, rhetoric, and legal analysis. London: Macmillan Publishers Limited.

26. Hall, Mark. A., and Ronald F. Wright. 2008. Systematic content analysis of judicial opinions. California Law Review 96: 63-122.

27. Amado, Barbara. G., Ramon Arce, and Francisca Fariña. 2015. Undeutsch hypothesis and Criteria Based Content Analysis: A meta-analytic review. The European Journal of Psychology Applied to Legal Context, 7(1): 1-10.

28. Hunter, Rosemary. 2015. Analyzing Judgments from a Feminist Perspective. Legal Information Management, 15(01): 8-11.

29. Vaezi, Sayeed H. 2015. The Roles of Ethic and Education from the Perspective of Religious Jurisprudence and Islamic Laws. JSR 2(19): 142-150.

30. Falk, Richard A. 2015. Status of Law in International Society. Princeton University Press. 